\title{
The Implementation of Take And Give Learning Methods With Portfolios To Improve The Biology Learning Outcomes Of Class II Students At SMA Pembangunan Bengkulu City
}

\section{Penerapan Metode Pembelajaran Take And Give Dengan Portofolio Untuk Meningkatkan Hasil Belajar Biologi Siswa Kelas II di SMA Pembangunan Kota Bengkulu}

\author{
Eka Nurdianty Anwar \\ Akademi Analis Kesehatan Harapan Bangsa Bengkulu \\ Email: eccka101083@yahoo.co.id
}

Recelled 4 Agustus 2020, Revised 30 September 2020, Accepted 30 Oktober 2020

\begin{abstract}
This study aims to improve social studies learning outcomes using the portfolio study method of class VI students of SMA Pembangunan Kota Bengkulu. This research took place in two cycles. The instruments used were observation sheets, test questions. Data were analyzed qualitatllely and quantitatllely. The efficiency indicator of this study is that if at least $70 \%$ of students have reached KKM, 70 and the average class experience increases every cycle. The results of the study show that the use of the stages of the portfolio study method that is identifying problems, selecting problems to be studied, gathering information, making portfolio classes, presenting portfolios, hearing opinions and making conclusions can improve Biologi learning outcomes. The cognitlle Biologi learning outcomes (tests) in the first cycle increased to $70.28 \%$ and the cycle II increased again to $91.90 \%$. The percentage of cognitlle domain Cllics learning outcomes (products) after the first cycle of action was shown to be $75.67 \%$, and the cycle II action increased to $91.40 \%$.
\end{abstract}

Keywords: Portfolio, competence, Learning Outcomes

\section{Abstrak}

Penelitian ini bertujuan untuk meningkatkan hasil belajar Biologi menggunakan metode studi portofolio siswa kelas VI SMA Pembangunan Kota Bengkulu. Penelitian ini berlangsung dalam dua siklus. Instrumen yang digunakan adalah lembar observasi, soal tes. Data dianalisis secara deskriptif kualitatif dan kuantitatif. Indikator Efisiensi penelitian ini adalah jika minimal 70\% siswa telah mencapai KKM yaitu 70 dan rata-rata pengalaman kelas peningkatan setiap siklusnya. Hasil penelitian menunjukkan bahwa penggunaan tahapan-tahapan metode studi portofolio yaitu mengidentifikasi masalah, memilih masalah yang akan diteliti, mengumpulkan informasi, membuat kelas portofolio, menyajikan portofolio, mendengar pendapat dan melakukan kesimpulan dapat meningkatkan hasil belajar Biologi. Hasil belajar Biologi ranah kognitif (tes) pada siklus I meningkat menjadi $70,28 \%$ dan pada tindakan siklus II meningkat lagi menjadi 91,90\%. Persentase hasil belajar Biologi ranah kognitif (produk) setelah dilakukan tindakan siklus I tampak hasilnya $75,67 \%$, dan pada tindakan siklus II meningkat menjadi $91,40 \%$.

Kata Kunci: Portofolio, kompetensi, Hasil Belajar. 


\section{A. Pendahuluan}

Secara umum Pendidikan Kewarganegaraan atau bisa dikenal dengan sebutan Biologi merupakan pelajaran di tingkat sekolah yang bertujuan menjadikan Warga Negara Indonesia menjadi warga negara yang baik dengan harapan mampu mendukung bangsa dan Negara secara utuh. Menjadi warga negara yang baik dapat dipupuk mulai dari lingkungan keluarga, sekolah, maupun lingkungan masyarakat. Salah satu cara untuk membentuk siswa menjadi warga negara yang baik dari lingkungan sekolah adalah dengan memberikan pembelajaran Biologi dengan benar.

Menurut pendapat Lips et (Sobirin Malian dan Suparman Marzuki, 2003: 7), mata pelajaran Biologi merupakan pelajaran yang menitikberatkan pada pembentukan karakter dan kesadaran pribadi pada setiap warga negaranya agar mampu melaksanakan hak-hak dan kewajibannya sebagai warga negara. Warga negara diharapkan menjadi insan yang mampu menempatkan segala sesuatu pada tempatnya, mengutamakan kepentingan umum di atas kepentingan pribadi, mau dan mampu bertoleransi dengan sesama, serta diharapkan memiliki jiwa demokratis. Tentunya, tujuan ini akan tercapai jika Biologi diberikan dan diajarkan dengan cara yang tepat.

Pencapaian kondisi pembelajaran yang berkualitas dan efektif menurut Moh. Uzer Usman (1989: 21-33), setidaknya ada yang menentukan keberhasilan belajar siswa, yaitu sebagai berikut : 1) melibatkan siswa aktif, 2) menarik minat dan perhatian siswa, 3) membangkitkan motllasi siswa, 4) prinsip indllidualitas, 5) peragaan dalam pembelajaran.

Salah satu syarat terlaksananya pembelajaran yang kondusif adalah terkait dengan profesionalisme. Profsionalisme guru sangatlah dibutuhkan guna terciptanya suasana proses pembelajaran yang efektif dan efisien dalam pengembangan siswa yang memiliki kemampuan beragam. Guru sebagai fasilisator dalam pendidikan harus mampu mefasilitasi siswa untuk mengembangkan kemampuannya yang beragam. Maksudnya tidak hanya memperhatikan hasil akhir tetapi juga harus memperhatikan proses pembelajaran di kelas. Selain itu guru juga harus dapat menggunakan metode, media, maupun model pembelajaran yang tepat sebagai upaya meningkatkan kualitas pendidikan.

Pemilihan berbagai metode, media, maupun model pembelajaran yang banyak jenisnya tentu harus dipertimbangkan sebelum digunakan, misalnya dengan memperhatikan beberapa aspek seperti materi yang akan disampaikan, tujuan pembelajaran, waktu yang tersedia serta hal-hal yang berkaitan dengan proses pembelajaran. Salah satu tantangan mendasar dalam pelajaran Biologi dewasa ini adalah mencari model pembelajaran inovatif yang memungkinkan bagi peningkatan kualitas dan kuantitas Pendidikan Kewarganegaraan. Dalam mata pelajaran Biologi diperlukan model pembelajaran yang mampu mengakomodasi siswa dalam mengembangkan potensinya masingmasing sebagai manusia demokratis. Model pembelajaran yang tidak sekedar menitikberatkan pada aspek kognitif tetapi juga memasukkan aspek seperti afektif dan psikomotorik agar menjadi warga negara yang demokratis.

Kondisi pembelajaran dialami di kelas II SMA Pembangunan Kota Bengkulu. Hasil belajar siswa masih rendah dari target KKM Biologi Kelas II yang telah ditetapkan yaitu 70. Hasil observasi yang ada, ketika siswa dihadapkan pada suatu materi pelajaran abstrak, siswa sangat kesulitan untuk menangkap informasi dan memahaminya. Hal ini dikarenakan siswa kelas II merupakan siswa yang sedang mengalami perubahan cara berpikir praoperasional ke operasional konkrit. Siswa belum mampu secara penuh menangkap informasi yang bersifat abstrak.

Pada pelaksanaan pembelajaran Biologi, siswa cenderung pasif, banyak mendengarkan materi yang disampaikan 
guru tanpa adanya timbal balik, belum diterapkan pembelajaran yang mengangkat nilai-nilai demokratis. Tak jarang banyak ditemukan siswa membuat gaduh, tidak memperhatikan penjelasan guru karena siswa merasa sulit memahami materi, terlebih tidak adanya daya tarik dalam penyampaian materi. Guru menggunakan model pembelajaran yang monoton. Guru menyampaikan materi, kemudian siswa latihan mengerjakan soal. Penyampaian materi oleh guru kurang jelas. Dari segi perhatian siswa sendiri masih kurang fokus ketika pembelajaran berlangsung. Terlebih lingkungan sekolah berada di tengah - tengah desa yang ramai, hal ini kadang membuat suasana menjadi tidak kondusif. Siswa sering memperhatikan lingkungan di luar kelas, sehingga materi yang telah diterima juga tidak sepenuhnya dapat diserap dengan baik. Akhirnya semua ini, menyebabkan pencapaian hasil belajar siswa yang meliputi kognitif, afektif, dan psikomotorik masih jauh dari Kriteria Ketuntasan Minimal (KKM) yang telah ditentukan.

Uraian di atas memberikan petunjuk bahwa agar proses belajar mengajar dapat berhasil dengan baik, siswa sebaiknya diajak untuk memanfaatkan semua alat inderanya. Guru berupaya untuk menampilkan rangsangan (stimulus) yang dapat diproses dengan berbagai indera. Berdasarkan berbagai alasan tersebut maka peneliti ingin memecahkan masalah hasil belajar siswa kelas II SMA PEMBANGUNAN melalui Model Pembelajaran Berbasis Portofolio (MPBP), karena model pembelajaran tersebut merupakan satu bentuk dari praktik pembelajaran Biologi. MPBP merupakan model pembelajaran yang dalam penerapannya memuat nilai-nilai demokratis, mampu mengembangkan aspek kognitif, afektif, dan psikomotorik. MPBP juga merupakan model pembelajaran yang menyenangkan serta membutuhkan indera ganda yang tentunya itu akan memberikan keuntungan bagi siswa seperti dengan teori yang disampaikan di atas.

\section{B. Metode Penelitian}

Penelitian ini dilaksanakan di SMA Pembangunan Kota Bengkulu. Penelitian dilaksanakan dari tanggal 06 13 April 2016 semester genap tahun pembelajaran 2015/2016. Subjek dalam penelitian ini adalah siswa Kelas VI SMA Pembangunan Kota Bengkulu yang berjumlah 38 siswa yang terdiri dari 23 siswa laki - laki dan 14 siswa perempuan. Agar pengamatan dalam penelitian ini memperoleh data yang otentik maka peneliti meminta bantuan 1 orang guru SMA Pembangunan Kota Bengkulu sebagai teman sejawat. Siswa di kelas ini dipilih sebagai subjek penelitian karena kelas ini merupakan kelas dimana peneliti bertugas mengajarkan Biologi. Obyek dalam penelitian tindakan kelas ini adalah:

\section{Prosedur Penelitian}

Di dalam PTK ini, model yang dipakai adalah model Kemmis dan Mc Taggart dari Deakin Unllersity Australia, yaitu model spiral. terdiri dari perencanaan, tindakan, observasi dan refleksi, seperti digambarkan di bawah ini:

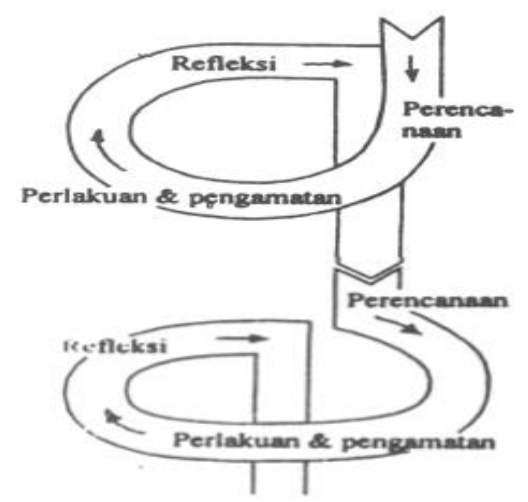

Gambar 1. Siklus Penelitian Tindakan Kelas

(Suharsimi Arikunto, dkk, 2007: 93)

Kegiatan pada masing-masing siklus mempunyai empat komponen yaitu tahap perencanaan (plan), pelaksanaan (action), observasi (observation), dan refleksi (reflection). Siklus II dan siklus III dilaksanakan apabila tahap-tahap pada siklus I tidak terlaksana dengan baik serta hasilnya belum maksimal. 
Tahap-tahap yang akan dilaksanakan pada siklus I sesuai FX. Soedarsono (1996: 16) dalam Pedoman Pelaksanaan Penelitian Tindakan Kelas, dijelaskan sebagai berikut.

\section{Tahap perencanaan (plan)}

Meliputi rencana tindakan apa yang akan dilakukan untuk memperbaiki, meningkatkan, atau merubah perilaku dan sikap sebagai solusi. Adapun kegiatannya yaitu : a). Menetapkan subyek penelitian yaitu siswa kelas III, dan tempat pembelajaran untuk mempermudah memperoleh data. b). Mengidentifikasi masalah kemudian mengambil masalah yang paling esensial. Di dalam PTK ini masalah yang diambil adalah hasil belajar siswa yang kurang dalam pembelajaran Biologi dikarenakan penilaian yang kurang tepat. c). Merumuskan tindakan untuk perbaikan dengan tepat dan sesuai yaitu dengan penilaian portofolio. d). Menyusun rencana penelitian berupa rangkaian kegiatan disertai siklus tindakannya

\section{Tahap pelaksanaan (action)}

Meliputi apa yang dilakukan guru atau peneliti sebagai upaya perbaikan, peningkatan, atau perubahan yang diinginkan. Kegiatan dalam tahap pelaksanaan ini yaitu setelah memperoleh gambaran tentang pembelajaran Biologi, bagaimana keadaan siswa, bagaimana guru menilai, kondisi kelas, serta sarana pembelajaran maka dilakukan tindakan yaitu penggunaan penilaian portofolio dalam pembelajaran Biologi sehingga ketiga aspek kemampuan siswa dapat dinilai dengan obyektif.

\section{Tahap observasi (observation)}

Meliputi kegiatan mengamati atas hasil atau dampak dan proses dari tindakan yang dilaksanakan atau dikenakan pada siswa. Tahap ini diperlukan adanya alat atau instrumen penelitian. Kegiatannya yaitu mengamati proses dan hasil bahwa penilaian portofolio sesuai digunakan dalam pembelajaran Biologi sehingga dapat meningkatkan hasil belajar siswa.

\section{Tahap refleksi (reflection)}

Disini peneliti mengkaji, melihat, dan mempertimbangkan atas proses dan hasil tindakan dari berbagai kriteria. Kegiatannya yaitu melakukan evaluasi untuk mengukur peningkatan hasil belajar siswa melalui berbagai instrumen apakah penilaian lebih efektif setelah diterapkan penilaian portofolio.

\section{Teknik Analisis Data}

Analisis data yang digunakan dalam penelitian ini adalah membandingkan aktifitas hasil belajar siswa kelas baik dari aspek kognitif, afektif, dan psikomotorik sebelum dan sesudah diberikan tindakan. Sedangkan hasil belajar adalah keluaran (output) dari suatu sistem pemrosesan masukan (input). Masukan dari sistem tersebut berupa macam-macam informasi, sedangkan keluarannya adalah perbuatan atau kinerja (performance). Data yang akan diteliti pada penelitian ini adalah : adalah :

Data yang diteliti pada penelitian ini

a. Data skor kemampuan guru merencanakan pembelajaran.

b. Data guru melaksanakan pembelajaran.

c. Data berupa nilai peningkatan hasil belajar siswa pada pembelajaran.

Penjelasan atas data yang

dianalisis itu adalah:

a. Data skor kemampuan guru dalam merencanakan pembelajaran dengan, dihitung menggunakan perhitungan ratarata $(X)$. Rumus untuk menghitung rata-rata tersebut digunakan rumus Anas Sudjiono (2010:81) sebagai berikut :

$$
M x=\frac{\sum x}{N}
$$

Keterangan :

$\mathrm{Mx}$ = Mean/rata-rata yang dicari

$\Sigma x \quad$ = jumlah seluruh skor yang diperoleh

$\mathrm{N} \quad=$ jumlah indicator 
b. Data skor kemampuan guru dalam melaksanakan pembelajaran, dihitung menggunakan perhitungan ratarata $(X)$ Rumus untuk menghitung rata-rata tersebut digunakan rumus (Anas Sudijono (2010:81) sebagai berikut:

$$
M x=\frac{\sum x}{N}
$$

$$
\begin{aligned}
& \text { Keterangan : } \\
& \text { Mx = Mean/rata-rata yang } \\
& \text { dicari } \\
& \Sigma x=\text { jumlah seluruh skor yang } \\
& \text { diperoleh } \\
& \mathrm{N} \quad=\text { jumlah indicator }
\end{aligned}
$$

c. Data hasil belajar siswa pada pelajaran BIOLOGI materi lingkungan rumah sehat. Data menggunakan perhitungan ratarata dan persentase menghitung rata-rata. menggunakan rumus Awalludin, dkk (2010:28) sebagai berikut :

$x=\frac{\sum f x}{\sum f}$

Keterangan :

$\mathrm{x}=$ Rata - rata hitung yang dicari

$\sum f=$ Jumlah frekuensi

$\sum f x=$ Banyaknya skor itu sendiri (number of case)

a. Hasil belajar siswa pada pelajaran Biologi materi lingkungan rumah sehat dihitung dengan menggunakan rumus sebagai berikut:

$$
M x=\frac{\sum n}{\sum s}
$$

Keterangan :

$\mathrm{Mx}=$ Mean / rata - rata

$\sum n=$ Jumlah nilai

$\sum s=$ jumlah siswa

\section{Kriteria Keberhasilan}

Penerapan metode demonstrasi pada pembelajran Biologi kelas II semester 2 materi lingkungan rumah sehat dalam penelitian ini dikategorikan berhasil jika:

a. Tingkat kemampuan guru dalam perencanaan maupun proses pembelajaran mencapai nilai kerja rerata $B$ (baik) antara 2,6-3,2.

b. Hasil rerata hasil pembelajaran siswa berada pada posisi KKM Biologi kelas II yaitu 65 atau $\geq 65$ dan ketuntasan belajar secara klasikal mencapai $80 \%$. Data berupa nilai hasil belajar siswa pada pembelajaran terdiri dari aspek kognitif dengan pencapaian KKM belum tuntas dan tuntas, sedangkan untuk hasil belajar ranah afektif, dan psikomotorik menggunakan pencapaian KKM Kurang baik dan baik.

\section{Kriteria Keberhasilan Tindakan}

Kriteria keberhasilan dalam penelitian ini adalah adanya peningkatan hasil belajar siswa yang meliputi tiga ranah yaitu ranah kognitif (tes dan produk), afektif, dan psikomotorik. Kriteria keberhasilan dari ketiga ranah tersebut untuk jelasnya kami sajikan dalam tabel di bawah ini.

Tabel 1. Kriteria Keberhasilan Penelitian

\begin{tabular}{|l|l|l|}
\hline \multirow{2}{*}{ Ranah yang Dinilai } & \multicolumn{2}{|l|}{ Kriteria Ketuntasan Minimal } \\
\cline { 2 - 3 } & Kuantitatif & Kualitati \\
\hline Kognitif (tes) & 71 & Tuntas \\
\hline Kognitif (produk) & 7 & Tuntas \\
\hline Afektif & 1 & Baik \\
\hline Psikomotorik & 4 & Baik \\
\hline
\end{tabular}

Proses

pembelajaran

menggunakan Model Pembelajaran Berbasis Portofolio dikatakan berhasil jika $75 \%$ dari jumlah siswa yang mengikuti proses pembelajaran telah mencapai kriteria keberhasilan yang telah ditentukan. 


\section{Hasil Penelitian dan Pembahasan Hasil Penelitian}

\section{SIKLUS I}

Untuk mengetahui peningkatan hasil belajar Biologi ranah kognitif maka dilakukan tes dan produk. Tes yang digunakan adalah post test. Soal- soal yang diujikan terdiri dari soal pilihan ganda dan uraian singkat. Produk yang dinilai merupakan hasil dari pembuatan portofolio. Hasil belajar ranah kognitif berupa produk portofolio merupakan ratarata nilai produk portofolio dokumentasi dan portofolio penayangan. Untuk hasil belajar Biologi ranah afektif dan psikomotorik melalui pengamatan saat proses pembelajaran.

Dari hasil nilai tes yang diolah menunjukkan bahwa ada kenaikan perolehan nilai kognitif jika dibandingkan dengan nilai pre test. Untuk ranah afektif dan psikomotorik yang sebelumnya tidak diperhatikan maka pada siklus I ini, kedua ranah tersebut mendapat perhatian dengan dilakukan penilaian. Dari hasil belajar Biologi pada siklus I, menunjukkan adanya peningkatan hasil belajar Biologi.

Sesuai dengan indikator ketercapaian tindakan, maka standar minimal yang digunakan untuk keberhasilan ranah kognitif adalah 71 , ranah afektif minimal mendapat skor 10 (baik), dan ranah psikomotorik minimal mendapat skor 4 (baik). Proses pembelajaran Biologi menggunakan Model Pembelajaran Berbasis Portofolio dikatakan berhasil apabila $75 \%$ dari jumlah siswa yang mengikuti proses belajar telah mencapai taraf keberhasilan minimal sebesar 71 untuk nilai ranah kognitif, minimal skor 10 (baik) untuk ranah afektif, dan minimal skor 4 (baik) untuk ranah psikomotorik.

Secara keseluruhan dapat dikatakan bahwa pelaksanaan tindakan siklus I, hasil belajar Biologi telah meningkat. Data selengkapnya mengenai hasil belajar Biologi dengan menggunakan Model Pembelajaran Berbasis Portofolio dapat dilihat pada tabel di bawah ini

Tabel 2. Hasil Belajar Biologi Ranah Kognitif (Tes)

\begin{tabular}{|c|c|c|c|c|}
\hline No & Nilai & $\begin{array}{c}\text { Jumlah } \\
\text { siswa }\end{array}$ & $\begin{array}{c}\text { Persentase } \\
(100 \%)\end{array}$ & Pencapaian KKM \\
\hline 1 & $\leq 40$ & 4 & 10,81 & belum tuntas \\
\hline 2 & $41-55$ & 4 & 10,81 & belum tuntas \\
\hline 3 & $56-70$ & 3 & 8,10 & belum tuntas \\
\hline 4 & $71-85$ & 23 & 62,18 & tuntas \\
\hline 5 & $86-100$ & 3 & 8,10 & tuntas \\
\hline
\end{tabular}

Tabel 3. Hasil Belajar Biologi Ranah Kognitif (Produk)

\begin{tabular}{|c|c|c|c|c|}
\hline No & Nilai & $\begin{array}{c}\text { Jumlah } \\
\text { siswa }\end{array}$ & $\begin{array}{c}\text { Persentase } \\
(100 \%)\end{array}$ & Pencapaian KKM \\
\hline 1 & $\leq 40$ & 0 & 0 & - \\
\hline 2 & $41-55$ & 3 & 8,10 & belum tuntas \\
\hline 3 & $56-70$ & 6 & 16,23 & belum tuntas \\
\hline 4 & $71-85$ & 28 & 75,67 & tuntas \\
\hline 5 & $86-100$ & 0 & 0 & - \\
\hline
\end{tabular}


Tabel 4. Hasil Belajar Biologi Ranah Afektif

\begin{tabular}{|r|c|c|c|c|}
\hline No & Nilai & $\begin{array}{c}\text { Jumlah } \\
\text { siswa }\end{array}$ & $\begin{array}{c}\text { Persentase } \\
(100 \%)\end{array}$ & Pencapaian KKM \\
\hline 1 & $<10$ & 7 & 18,92 & kurang baik \\
\hline 2 & $10-12$ & 9 & 24,32 & baik \\
\hline 3 & $13-15$ & 21 & 56,76 & sangat baik \\
\hline
\end{tabular}

Tabel 5. Hasil Belajar Biologi Ranah Psikomotorik

\begin{tabular}{|c|c|c|c|c|}
\hline No & Nilai & $\begin{array}{c}\text { Jumlah } \\
\text { siswa }\end{array}$ & $\begin{array}{c}\text { Persentase } \\
(100 \%)\end{array}$ & Pencapaian KKM \\
\hline 1 & $\leq 3$ & 7 & 18.92 & kurang baik \\
\hline 2 & $4-6$ & 12 & 32.43 & baik \\
\hline 3 & $7-9$ & 18 & 48,65 & sangat baik \\
\hline
\end{tabular}

Dari hasil penilaian ranah kognitif (tes) yang telah dilaksanakan menunjukkan bahwa sebagian besar siswa telah mencapai KKM (Kriteria Ketuntasan Minimal), yaitu $\geq 71$. Dari jumlah keseluruhan siswa, $70,28 \%$ atau 26 siswa telah mencapai nilai KKM yang ditentukan. Sedangkan $29,72 \%$ dari jumlah siswa atau 11 siswa yang belum mencapai nilai KKM. Nilai tertinggi yang diperoleh pada siklus I yaitu 90, sedangkan nilai terendahnya yaitu 32 . Jumlah nilai seluruh siswa yaitu 2.634 dan rata-rata nilai kelas sebesar 71,19 . Hal ini berarti telah memenuhi standar minimal yang telah ditentukan.

Dari hasil penilaian ranah kognitif (produk) yang telah dilaksanakan menunjukkan bahwa sebagian besar siswa telah mencapai KKM (Kriteria Ketuntasan Minimal), yaitu $\geq 71$. Dari jumlah keseluruhan siswa, $75,67 \%$ atau 28 siswa telah mencapai nilai KKM yang ditentukan. Sedangkan $24,33 \%$ dari jumlah siswa atau 9 siswa yang belum mencapai nilai KKM. Nilai tertinggi yang diperoleh pada siklus I yaitu 79, sedangkan nilai terendahnya yaitu 54 . Jumlah nilai seluruh siswa yaitu 2.629 dan rata-rata nilai kelas sebesar 71,05 . Hal ini berarti telah memenuhi standar minimal yang telah ditentukan.

Berdasarkan hasil penilaian ranah afektif yang telah dilaksanakan menunjukkan bahwa sebagian besar siswa telah mencapai skor minimal yaitu $\geq 10$. Dari jumlah keseluruhan siswa, $81,08 \%$ atau 30 siswa telah mencapai skor minimal yang ditentukan. Sedangkan sebesar $18,92 \%$ atau 7 siswa yang belum mencapai skor minimal. Skor tertinggi yang diperoleh siswa pada siklus I yaitu 15, sedangkan skor terendahnya 5 . Jumlah skor seluruh siswa yaitu 431 dan rata-ratanya sebesar 11,65. Hal ini berarti telah memenuhi standar minimal yang ditentukan.

Untuk hasil penilaian ranah psikomotorik yang telah dilaksanakan menunjukkan bahwa siswa telah mencapai skor standar yang ditentukan, yaitu $\geq 4$. Dari jumlah keseluruhan siswa, $81,08 \%$ atau 30 siswa telah mencapai skor standar yang ditentukan. Sedangkan $18,92 \%$ atau 3 siswa belum mencapai skor minimal. Skor tertinggi 9 dan skor terendah 3. Jumlah skor seluruh siswa yaitu 228 dan rata-ratanya 6,16. Untuk ranah psikomotorik, jauh di atas standar yang ditentukan yaitu $81,08 \%$ dari jumlah siswa telah memenuhi skor minimal.

Data mengenai hasil penilaian ranah kognitif, afektif, maupun psikomotorik selengkapnya dapa dilihat pada lampiran penelitian ini. Setelah siklus I penelitian tindakan ini dilakukan, maka langkah selanjutnya adalah melakukan refleksi. Kegiatan ini dilakukan antara observer dengan guru kelas II (peneliti) pada hari Sabtu, 09 April 2016 di ruang guru. Langkah refleksi dilakukan dengan melakukan evaluasi terhadap semua yang terjadi selama tindakan penelitian dilaksanakan. Kegiatan refleksi yang dilakukan berupa membandingkan antara keadaan sebelum dan setelah dilakukan tindakan. Peningkatan hasil belajar siswa 
dari penggunaan Model Pembelajaran Berbasis Portofolio dalam proses pembelajaran Biologi dapat diketahui dengan membandingkan hasil belajar sebelum diberi tindakan dengan hasil belajar siklus I setelah diberi tindakan. Adapun perbandingan yang telah dilakukan dapat dijelaskan dengan tabel di bawah ini:

Tabel 6. Perbandingan Hasil Belajar Biologi

\begin{tabular}{|c|c|c|c|c|c|c|}
\hline \multirow{3}{*}{$\begin{array}{l}\text { Hasil Belajar } \\
\text { Biologi }\end{array}$} & \multirow{2}{*}{\multicolumn{2}{|c|}{$\begin{array}{c}\text { Sebelum } \\
\text { Diberi Tindakan } \\
\text { Jumlah Siswa } \\
\end{array}$}} & \multirow{2}{*}{\multicolumn{2}{|c|}{$\begin{array}{c}\text { Tindakan Siklus } \\
\text { I } \\
\text { Jumlah Siswa }\end{array}$}} & \multirow{3}{*}{ 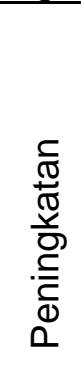 } & \multirow{3}{*}{ 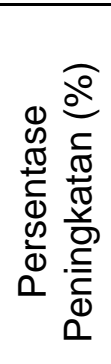 } \\
\hline & & & & & & \\
\hline & 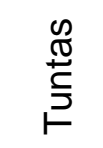 & 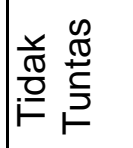 & $\underset{\stackrel{N}{\overparen{T}}}{\stackrel{\mathscr{T}}{5}}$ & 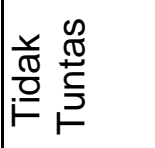 & & \\
\hline Kognitif (tes) & 14 & 23 & 26 & 9 & 13 & 29,10 \\
\hline Kognitif (produk) & - & - & 34 & 3 & 34 & 91,89 \\
\hline Afektif & - & - & 31 & 6 & 31 & 83,78 \\
\hline Psikomotorik & - & - & 30 & 7 & 30 & 81,08 \\
\hline
\end{tabular}

Hasil refleksi yang telah dilakukan pada siklus I adalah adanya peningkatan hasil belajar Biologi siswa kelas II SMA Pembangunan Kota Bengkulu. Kekurangan dalam siklus I adalah guru belum optimal menguasai kondisi kelas. Siswa tersebut justru melontarkan pertanyaan-pertanyaan di luar materi kepada guru. Banyak siswa yang masih tampak kebingungan dalam mengikuti alur pembelajaran sehingga siswa yang mau mendengarkan hanya sedikit. Siswa yang bingung cenderung pasif dalam kelompok dan buruknya lagi tidak mau bertanya kepada guru. Beberapa siswa lain juga masih sibuk dengan kegiatannya sendiri seperti berbicara dengan teman, jalan-jalan, dan memukul-mukul meja sambil bernyanyi. Dengan demikian peneliti perlu melanjutkan tindakan untuk siklus II agar lebih memantapkan peningkatan hasil belajar Biologi menggunakan Model Pembelajaran Berbasis Portofolio dalam proses pembelajaran Biologi Kelas II.

\section{SIKLUS II}

Pada siklus II ini materi yang digunakan dipertajam dari materi pada siklus I. Dengan begitu peneliti akan mendapatkan data yang lebih mendukung bahwa penggunaan Model
Pembelajaran Berbasis Portofolio ini cocok diterapkan dalam pembelajaran Biologi karena dapat meningkatkan hasil belajar Biologi. Selain materi diperdalam, perbedaan tindakan pada siklus I dan siklus II lainnya adalah pada media yang digunakan, media yang digunakan untuk mengumpulkan informasi adalah media elektronik berupa internet, media portofolio penayangan menggunakan infocus dan untuk pembuatannya lebih dibebaskan untuk mengembangkan kreatifitas siswa.

Adapun kompetensi dasar yang akan dicapai siswa pada siklus II ini yaitu "Menentukan sikap terhadap globalisasi yang terjadi dilingkungannya". Dari kompetensi dasar tersebut, indikator serta tujuan pembelajaran yang ingin dicapai adalah: (1) Menentukan sikap terhadap pengaruh positif globalisasi yang terjadi di lingkungannya; (2) Menentukan sikap terhadap pengaruh negatif globalisasi yang terjadi di lingkungannya.

Waktu yang dialokasikan dalam pelaksanaan siklus II ini adalah $1 \mathrm{kali}$ pertemuan. Akan tetapi sebelum dilakukan pertemuan pertama, guru telah melakukan 2 kali pertemuan di luar jam pelajaran. Hal ini dilalukan karena 2 kali pertemuan itu hanya membutuhkan waktu yang 
sebentar, tidak mencapai satu jam pelajaran. Pertemuan pertama berlangsung kurang lebih 15 menit, untuk pembentukan kelompok kecil dan pemberian PR. Pembentukan kelompok pada siklus II ini diserahkan penuh kepada siswa. Siswa diberi kebebasan seluasluasnya untuk menentukan kelompoknya masing-masing. Hal ini berbeda dengan siklus I, dimana pembentukan kelompok ditentukan oleh guru. Pada siklus II ini, guru menerapkan nilai- nilai demokrasi dengan lebih mendalam. Pemberian keleluasaan dalam memilih teman kelompok tampak memberikan kepercayaan diri terhadap diri siswa. Siswa bersemangat dalam merencanakan belajar kelompok untuk mengerjakan tugas LKS, tugas LKS yang diberikan sama dengan tugas pada siklus I, yaitu mencari sebanyak-banyaknya bidang kehidupan manusia yang terpengaruh oleh globalisasi.

Untuk mengetahui peningkatan hasil belajar Biologi ranah kognitif maka dilakukan tes. Tes yang digunakan adalah post test. Soal-soal yang diujikan terdiri dari soal pilihan ganda dan uraian singkat. Untuk hasil belajar Biologi ranah afektif dan psikomotorik melalui pengamatan saat proses pembelajaran. Sesuai dengan indikator ketercapaian tindakan, maka standar minimal yang digunakan untuk keberhasilan ranah kognitif adalah 71 , ranah afektif minimal mendapat skor 10 (baik), dan ranah psikomotorik minimal mendapat skor 4 (baik). Proses pembelajaran Biologi menggunakan Model Pembelajaran Berbasis Portofolio dikatakan berhasil apabila $75 \%$ dari jumlah siswa yang mengikuti proses belajar telah mencapai taraf keberhasilan minimal sebesar 71 untuk nilai ranah kognitif, minimal skor 10 (baik) untuk ranah afektif, dan minimal skor 4 (baik) untuk ranah psikomotorik. Secara keseluruhan dapat dikatakan bahwa pelaksanaan tindakan siklus II hasil belajar Biologi meningkat. Data selengkapnya mengenai hasil belajar Biologi menggunakan Model Pembelajaran Berbasis Portofolio pada proses pembelajaran siklus II dapat dilihat pada tabel di bawah ini:

Tabel 7. Hasil Belajar Biologi Ranah Kognitif (tes)

\begin{tabular}{|c|c|c|c|c|}
\hline No & Nilai & $\begin{array}{c}\text { Jumlah } \\
\text { siswa }\end{array}$ & $\begin{array}{c}\text { Persentase } \\
(100 \%)\end{array}$ & Pencapaian KKM \\
\hline 1 & $\leq 40$ & 0 & 0 & - \\
\hline 2 & $41-55$ & 1 & 2,70 & belum tuntas \\
\hline 3 & $56-70$ & 2 & 5,40 & belum tuntas \\
\hline 4 & $71-85$ & 28 & 75,68 & tuntas \\
\hline 5 & $86-100$ & 6 & 16,22 & tuntas \\
\hline
\end{tabular}

Tabel 8. Kognitif (Produk)

\begin{tabular}{|c|c|c|c|c|}
\hline No & Nilai & $\begin{array}{c}\text { Jumlah } \\
\text { siswa }\end{array}$ & $\begin{array}{c}\text { Persentase } \\
(100 \%)\end{array}$ & Pencapaian KKM \\
\hline 1 & $\leq 40$ & 0 & 0 & - \\
\hline 2 & $41-55$ & 1 & 2,70 & belum tuntas \\
\hline 3 & $56-70$ & 2 & 5,40 & belum tuntas \\
\hline 4 & $71-85$ & 32 & 86,50 & tuntas \\
\hline 5 & $86-100$ & 2 & 5,40 & tuntas \\
\hline
\end{tabular}


Tabel 9. Hasil Belajar Biologi Ranah Afektif

\begin{tabular}{|c|c|c|c|c|}
\hline No & Nilai & $\begin{array}{c}\text { Jumlah } \\
\text { siswa }\end{array}$ & $\begin{array}{c}\text { Persentase } \\
(100 \%)\end{array}$ & Pencapaian KKM \\
\hline 1 & $<10$ & 2 & 5,40 & kurang baik \\
\hline 2 & $10-12$ & 11 & 29,73 & baik \\
\hline 3 & $13-15$ & 24 & 64,87 & sangat baik \\
\hline
\end{tabular}

Tabel 10. Hasil Belajar Biologi Ranah Psikomotorik

\begin{tabular}{|c|c|c|c|c|}
\hline No & Nilai & $\begin{array}{c}\text { Jumlah } \\
\text { siswa }\end{array}$ & $\begin{array}{c}\text { Persentase } \\
(100 \%)\end{array}$ & Pencapaian KKM \\
\hline 1 & $\leq 3$ & 3 & 8,10 & kurang baik \\
\hline 2 & $4-6$ & 14 & 37,84 & baik \\
\hline 3 & $7-9$ & 20 & 54,06 & sangat baik \\
\hline
\end{tabular}

Hasil penilaian ranah kognitif (tes) yang telah dilaksanakan menunjukkan bahwa sebagian besar siswa telah mencapai KKM (Kriteria Ketuntasan Minimal), yaitu $\geq 71$. Dari jumlah keseluruhan siswa, 91,90\% atau 34 siswa telah mencapai nilai KKM yang ditentukan. Sedangkan 8,10\% dari jumlah siswa atau 3 siswa yang belum mencapai nilai KKM. Nilai tertinggi yang diperoleh pada siklus II yaitu 100, sedangkan nilai terendahnya yaitu 55. Jumlah nilai seluruh siswa yaitu 2.935 dan rata-rata nilai kelas sebesar 79,32. Hal ini berarti telah memenuhi standar minimal yang telah ditentukan.

Hasil penilaian ranah kognitif (produk) yang telah dilaksanakan menunjukkan bahwa semua siswa telah mencapai KKM (Kriteria Ketuntasan Minimal), yaitu $91,40 \%$ atau 34 siswa. Sedang siswa belum mencapai KKM ada 3 siswa atau $8,10 \%$. Nilai tertinggi yang diperoleh pada siklus II yaitu 90, sedangkan nilai terendahnya yaitu 50 . Jumlah nilai seluruh siswa yaitu 2,696 dan rata-rata nilai kelas sebesar 72,86 . Hal ini berarti telah memenuhi standar minimal yang telah ditentukan.

Berdasarkan hasil penilaian ranah afektif yang telah dilaksanakan menunjukkan bahwa sebagian besar siswa telah mencapai skor minimal yaitu $\geq 10$. Dari jumlah keseluruhan siswa, $94,60 \%$ atau 35 siswa telah mencapai skor minimal yang ditentukan. Sedangkan sebesar $5,40 \%$ atau 2 siswa yang belum mencapai skor minimal. Skor tertinggi yang diperoleh siswa pada siklus II yaitu 15, sedangkan skor terendahnya 7 . Jumlah skor seluruh siswa yaitu 391 dan rata-ratanya sebesar 10,57. Hal ini berarti telah memenuhi standar minimal yang ditentukan.

Untuk hasil penilaian ranah psikomotorik yang telah dilaksanakan menunjukkan bahwa siswa telah mencapai skor standar yang ditentukan yaitu $\geq 4$. Dari jumlah keseluruhan siswa, $91,90 \%$ atau 34 siswa telah mencapai skor standar yang ditentukan. Sedangkan $8,10 \%$ atau 3 siswa belum mencapai skor minimal. Skor tertinggi 9 dan skor terendah 3 . Jumlah skor seluruh siswa yaitu 243 dan rata-ratanya 6,57. Untuk ranah psikomotorik, jauh di atas standar yang ditentukan yaitu $91,90 \%$ dari jumlah siswa telah memenuhi skor minimal. Data mengenai hasil penilaian ranah kognitif, afektif, maupun psikomotorik selengkapnya dapat dilihat pada lampiran penelitian ini.

\section{Refleksi Pelaksanaan Tindakan II}

Kegiatan refleksi dilakukan antara peneliti dengan pada hari Sabtu, 16 April 2016 di ruang guru. Peneliti bersama observer membandingkan antara keadaan setelah dilakukan tindakan siklus I dan siklus II. Perbandingan dilakukan untuk mengetahui kenaikan atau penurunan hasil belajar Biologi. Adapun perbandingan yang telah dilakukan dapat dijelaskan dengan tabel di bawah ini: 
Tabel 11. Perbandingan Hasil Belajar Biologi

\begin{tabular}{|c|c|c|c|c|c|c|}
\hline \multirow{3}{*}{$\begin{array}{c}\text { HASIL BELAJAR } \\
\text { Biologi }\end{array}$} & \multicolumn{2}{|c|}{$\begin{array}{l}\text { SEBELUM } \\
\text { DIBERI } \\
\text { TINDAKAN }\end{array}$} & \multicolumn{2}{|c|}{$\begin{array}{c}\text { TINDAKAN } \\
\text { SIKLUS I }\end{array}$} & \multicolumn{2}{|c|}{$\begin{array}{l}\text { TINDAKAN } \\
\text { SIKLUS II }\end{array}$} \\
\hline & \multicolumn{2}{|c|}{ Jumlah Siswa } & \multicolumn{2}{|c|}{ Jumlah Siswa } & \multicolumn{2}{|c|}{ Jumlah Siswa } \\
\hline & $\underset{\stackrel{N}{\leftrightarrows}}{\stackrel{N}{5}}$ & 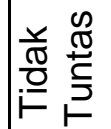 & $\stackrel{\frac{9}{\pi}}{\stackrel{2}{5}}$ & 毫䍃 & 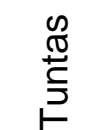 & 离 \\
\hline Kognitif (tes) & $\overline{14}$ & 23 & 26 & 11 & 34 & 3 \\
\hline Kognitif (produk) & - & - & 34 & 3 & 34 & 3 \\
\hline Afektif & - & - & 31 & 6 & 35 & 2 \\
\hline Psikomotorik & - & - & 30 & 7 & 34 & 3 \\
\hline
\end{tabular}

Berdasarkan data di atas, dapat disimpulkan bahwa hasil belajar Biologi mengalami peningkatan setelah dilaksanakannya pembelajaran menggunakan Model Pembelajaran Berbasis Portofolio.

\section{Pembahasan}

Penelitian tindakan ini dilaksanakan dalam dua siklus. Siklus I dilaksanakan 1 kali pertemuan sesuai jam pelajaran. Siklus II dilaksanakan 2 (dua) kali pertemuan sesuai jam pelajaran dan 2 (dua) kali pertemuan di luar jam pelajaran. Berikut ini akan dibahas beberapa hal terkait dengan penggunaan Model Pembelajaran Berbasis Portofolio untuk meningkatkan hasil belajar Biologi siswa kelas II SMA Pembangunan Kota Bengkulu.

Paradigma baru pendidikan menghendaki adanya inovasi yang terintegrasi dan berkesinambungan. Salah satu wujudnya adalah inovasi yang dilakukan guru dalam kegiatan pembelajaran di kelas. Seperti yang telah dipaparkan pada bab II, Boediono (Dasim Budimansyah, 2002: 3) mengungkapkan, penerapan Model Pembelajaran Berbasis Portofolio merupakan bentuk dari inovasi belajar kewarganegaraan, yaitu inovasi pembelajaran yang dirancang untuk membantu siswa memahami teori secara mendalam melalui pengalaman belajar praktik-empirik. Praktik belajar ini dapat menjadi program pendidikan yang mendorong kompetensi, tanggung jawab, dan partisipasi siswa, dan memberanikan diri siswa untuk berperan serta dalam kegiatan antarsiswa, antarsiswa, antarsekolah, dan antaranggota masyarakat.

Dalam pembelajaran dengan menggunakan Model Pembelajaran Berbasis Portofolio tidak menghendaki hanya satu pihak saja yang aktif tetapi menuntut keaktifan dari berbagai pihak dalam hal ini adalah guru dan siswa. Guru yang berperan sebagai fasilisator dan motllator tidak lagi hanya bertugas memberikan informasi kepada siswa tetapi tugas guru saat ini diharapkan dapat memotllasi siswa untuk mencari informasi baru di luar kelas sekolah, sehingga belajar juga dapat dilakukan di luar kelas. Guru tidak harus selalu memberikan materi yang sudah jadi atau matang kepada siswa, tetapi sebaliknya siswa harus mencari informasi sesuai dengan materi yang dipelajari. Guru di sini bertugas memberikan rambu-rambu yang harus dilaksanakan siswa dalam upaya mencari informasi di luar kelas.

Seperti yang telah dipaparkan juga pada bab II, pembelajaran berbasis portofolio menurut Arnie Fajar (2006: 45), memungkinkan siswa untu k:Merumuskan langkah yang akan dilakukan untuk mengatasi masalah dan mencegah timbulnya masalah yang berkaitan dengan topik yang dibahas.

Pelaksanaan penelitian dalam siklus I dan II menggunakan sumber belajar berupa media cetak dan media elektronik. Siswa dalam kesempatan ini berlatih memadukan antara konsep yang diperoleh dari penjelasan guru dan dari 
berbagai sumber belajar lain. Siswa mendapat kesempatan untuk mengakses informasi di luar kelas baik informasi yang sifatnya benda/bacaan, audio-video (TV/radio/internet). Siswa dilatih untuk membuat suatu keputusan yang berkaitan dengan konsep yang telah dipelajarinya, dengan mempertimbangkan nilai-nilai yang ada di masyarakat.

Sependapat dengan Arnie Fajar, bahwa pembelajaran berbasis portofolio seperti di atas akan membangun bermacam-macam kemampuan siswa dengan berpusat pada siswa. Artinya, upaya untuk memandirikan siswa untuk belajar, berkolaborasi, membantu teman, mengadakan observasi (pengamatan), dan penilaian diri untuk suatu refleksi akan mendorong siswa membangun pengetahuannya sendiri.

Pada dasarnya portofolio sebagai model pembelajaran merupakan usaha yang dilakukan guru agar siswa memiliki kemampuan untuk mengungkapkan dan mengekspresikan dirinya sebagai diri sendiri maupun makhluk sosial. Kemampuan tersebut diperoleh siswa melalui pengalaman belajar sehingga kemampuan mengolah informasi yang diperoleh, membuat laporan dan menuliskan apa yang dalam pikirannya, selanjutnya dituangkan penuh dalam tugas-tugas. (Arnie Fajar, 2002: 47) Penggunaan Model Pembelajaran Berbasis Portofolio pada mata pelajaran Biologi siswa kelas II SMA Pembangunan Kota Bengkulu secara umum dapat meningkatkan hasil belajar siswa.

Hasil belajar Biologi siswa pada siklus I menunjukkan bahwa pada ranah kognitif (tes) meningkat menjadi 70,28\% siswa telah mencapai nilai KKM, pada ranah kognitif (produk) meningkat menjadi $75,67 \%$ siswa telah mencapai nilai KKM, pada ranah afektif siswa yang telah mencapai skor standar (baik) adalah $81,08 \%$, dan pada ranah psikomotorik siswa yang telah mencapai skor standar adalah $81,08 \%$. Hasil belajar Biologi pada siklus II menunjukkan peningkatan hasil belajar Biologi dibandingkan dengan siklus I. Hasil belajar Biologi siklus II ranah kognitif (tes) menunjukkan 91,90\% siswa yang telah mencapai KKM, ranah kognitif (produk) menunjukkan 91,40\% siswa yang telah mencapai $\mathrm{KKM}$, ranah afektif 94,60\%, siswa telah mencapai skor standar, dan ranah psikomotorik $91,90 \%$. Dengan adanya peningkatan hasil belajar Biologi dari sebelum diberi tindakan dan sesudah diberi tindakan pada proses pembelajaran siklus I dan siklus II ini, maka dapat ditarik kesimpulan bahwa penggunaan Model Pembelajaran Berbasis Portofolio pada pelajaran Biologi siswa kelas II SMA Pembangunan Kota Bengkulu dapat meningkatkan hasil belajar.

\section{Kesimpulan dan Saran Kesimpulan}

Berdasarkan analisis data dan pembahasan maka dapat diambil kesimpulan bahwa: hasil belajar Biologi ranah kognitif (tes) pada siklus I meningkat menjadi $70,28 \%$ dan pada tindakan siklus II meningkat lagi menjadi 91,90\%. Persentase hasil belajar Biologi ranah kognitif (produk) setelah dilakukan tindakan siklus I tampak hasilnya $75,67 \%$, dan pada tindakan siklus II meningkat menjadi $91,40 \%$.

\section{Saran}

Penerapan Model Pembelajaran Berbasis Portofolio dalam upaya untuk meningkatkan hasil belajar siswa maka dapat diberikan saran-saran sebagai berikut guru dapat menerapkan Model Pembelajaran Berbsis Portofolio sebagai model pembelajaran alternatif dalam menyampaikan materi mata pelajaran Biologi untuk siswa kelas II di SMA Pembangunan Kota Bengkulu. Guru dalam pelaksanaan proses pembelajaran khususnya pada mata pelajaran Biologi sebaiknya senantiasa menanamkan nilainilai demokrasi. 


\section{Daftar Pustaka}

Anita Lie. (1997). Cooperatlle Learning. Jakarta : Grasindo.

Anita Yus, (2006). Penilaian Portofolio untuk Sekolah Dasar. Departemen Pendidikan Nasional. Direktorat Jenderal Pendidikan Tinggi.

Direktorat Ketenagaan.

Arnie Fajar. (2005). Portofolio dalam Pembelajaran BIOLOGI

Bandung:PT Remaja RoSMA Pembangunanakarya.

Azhar Arsyad. (1996). Media Pembelajaran. Jakarta: Raja Grafindo Persadaj

Dasim Budimansyah. (2002). Model Pembelajaran dan Penilaian Berbasis Portofolio. Bandung: PT. Genesindo.

Nana Sudjana. (2006). Penilaian Hasil Proses Belajar Mengajar. Bandung: Remaja RoSMA Pembangunana Karya

Suharsimi Arikunto, dkk. (2007). Penelitian Tindakan Kelas. Jakarta : Bumi Aksara.

Sumarna Surapranata dan

Penilaian Portofolio Impelementasi Kurikulum 2004. Bandung: PT Remaja RoSMA Pembangunanakarya (2005). Pendidikan Kewarganegaraan. Jakarta : PT Gramedia Pustaka Utama.

(2003). Undang-Undang Republik Indonesia No. 20 Tahun 2003 TentangSistem Pendidikan Nasional (SiSMA Pembangunaniknas). Bandung : Citra Umbara. . (2006). Kurikulum Tingkat Satuan Pendidikan Sekolah Dasar. Jakarta: Dikdasmen. 